\title{
Regional Disparities in the Economic Sphere: Evidence from the Selected Countries of the European Union
}

\author{
K. Gajdová and P. Tuleja
}

\begin{abstract}
Regional disparities, respectively regional differences, are in many spheres. For example it is social sphere, economic sphere and territorial sphere. This article is focused on regional disparities in the economic sphere. There is analysis of selected countries of European Union. The aim of this article is to analyse of the development of regional economic disparities. In this article there are individual issues always characterized. There is analysis of selected areas as economic potential, development potential and human potential. There are always assigned selected indicators for each area. Data are processed in graphic form. Finally, everything is summed up in a final table.
\end{abstract}

Index Terms-Regional disparities, economic sphere, development, European Union.

\section{INTRODUCTION}

Regional disparities are recently very often monitored concepts. Among the countries there are various differences of the development. They are regional disparities. The regional disparities exist in several areas. This article is focused on regional disparities in the economic sphere.

The aim of this article is to analyse of the development of regional economic disparities of the EU countries. It is focused on selected countries as Belgium, the Czech Republic, Hungary, Portugal and Sweden. The common main criterion of these countries is the number of inhabitants. There are from 9 million to 11 million of inhabitants.

The analysis of economic regional disparities is a very interesting and important area and it is a large area. More research of the economic indicators of selected countries will be subject of further examination.

\section{LITERATURE REVIEW}

Reference [1] shows the subject of interest, in the area of regional disparities, are complicated social objects. It means there is the uneven development of individual parts of these objects. It is reflected in the inequality or differences in these parts are called as disparity. Ministry of regional development $\mathrm{CZ}$ defines the regional disparities as "unfounded regional differences in the economic, social and environmental development of the regions" [2].

The basic classification of disparities based on the sphere

Manuscript received September 10, 2013; revised November 13, 2013 This research was financially supported by the Student Grant Competition SU within the project SGS/7/2012 "The influence of regional disparities on the business environment".

K. Gajdová and P. Tuleja are with the Department of Economics, School of Business Administration, Silesian University, 73340 Czech Republic (e-mail: gajdova@opf.slu.cz, tuleja@opf.slu.cz). of regional disparities occurrence. [3] We can find tree types of spheres of regional disparities occurrence the most authors agreed with. Regional disparities occur in the areas of social, economic and territorial.

Economic disparities are related to the regional economic performance, the structure of the regional economy, the development potential and the human potential. [4] We can include indicators of employment, unemployment, gross domestic product, labour productivity, industry, science and research, etc. [5]

Social disparities are related to the population in the wider context of quality of life, standard of living, social equality. We can monitor the population density, demographic structure, migration, occupations, job mobility, health, etc.

Territorial disparities are associated with geographic, natural, transport and technical conditions. [6] In this group we can include as area, climate, air, water, nature, waste, forests, transport infrastructure, technical infrastructure, etc.

It is usually at the discretion of the authors which indicators are included in the each spheres of occurrence.

\section{Methodology and Data}

The European Union currently has 27 countries. In July 2013 there will be a change and there will be 28 countries, because Croatia also joins the European Union. These countries differ, inter alia, in the number of population. [7] For this analysis are selected countries which have from 9 million to 11 million of inhabitants. The reason is the similarity of the population such as the Czech Republic (authors are from this country) which has 10474600 million of inhabitants. Countries which fulfil this criterion are Belgium, the Czech Republic, Hungary, Portugal and Sweden.

This analysis is focused on the period 2000-2011. In this period there are monitored all of the selected indicators. Data are taken from publicly available sources, from Eurostat. For each indicator that affects the regional disparities in the economic sphere there is monitored the development and then there is calculated the percentage change and the average rate of growth.

It has been calculated annual (or monthly) changes in selected indicators in the countries of the European Union. [8] The change in the selected indicators expresses the $\%$ change in the indicator in the monitored period compared to the same period last year.

$$
g_{x ; n}=\frac{w_{x ; t}-w_{x ; t-1}}{w_{x ; t-1}} \times 100
$$

Subsequently, it was calculated the average growth rate of selected indicator. We measure the average rate of growth by 
the geometric average of annual growth rates.

$$
G\left(g_{x ; 1}, g_{x ; 2}, \ldots, g_{x ; n}\right)=\sqrt[n]{g_{x ; 1}, g_{x ; 2}, \ldots, g_{x ; n}}=\left(\prod_{i=1}^{n} g_{x ; i}\right)^{\frac{1}{n}}
$$

The calculation results are summarized in the final table after it the sequence is scored.

\section{ECONOMIC SPHERE}

The economic performance of the region is a very important factor for development. It is a key attribute of the current level and one of the crucial aspects for comparison with other countries. Disparities in the economic sphere are divided into three units: economic potential, development potential and human potential.

\section{A. Economic Potential}

The economic potential of the region can be described for example in economic performance, labour productivity, industrial structure, external relationships regions, etc. We have focused on economic performance and international trade relations in our analysis of economic potential.

The economic performance is measured by aggregate macroeconomic indicators. [9] Aggregate indicator which is the most used is the gross domestic product. It is a key indicator of the development of the national economy. GDP (gross domestic product) is an indicator for a nation's economic situation. It reflects the total value of all goods and services produced less the value of goods and services used for intermediate consumption in their production.

Fig. 1 shows the development of the gross domestic products in selected countries in the years 2000-2011. It is expressed in PPS per inhabitant.

Expressing GDP in PPS (purchasing power standards) eliminates differences in price levels between countries, and calculations on a per head basis allows for the comparison of economies significantly different in absolute size.

The figure shows level of GDP in Belgium and Sweden is at the higher level than it is in other countries. In Sweden there is GDP which is developing from 24300 to 31900 . [10] In Belgium there is GDP which is developing from 24000 to 29900. These are high values. The contrast, in the country with the lowest level of GDP there are the development of values from 10300 to 16500 . It is Hungary, the country with a lot of problems. [11] Problems associated with the economic governance and with the external economic influences.

However when we look at the average growth rate of GDP, Hungary is among the top places. The average growth rate of GDP is showed in Table I in the last chapter.

The average growth rate of GDP is the highest in Belgium $(20.180 \%)$. It is followed by Hungary (4.376 \%), Czech Republic (3.684\%), Sweden $(2.504 \%)$. The last in this comparison is Portugal, where the average increase of GDP is $2.108 \%$ )

International trade relations are also one of the indicators describing the economic potential of the region. International trade relations represent the performance of individual regions in the field of export. These allow comparison among countries. International trade relations have an important role in today's globalized world in every economy. Foreign trade is a key to its development depends on the level of GDP and other indicators.

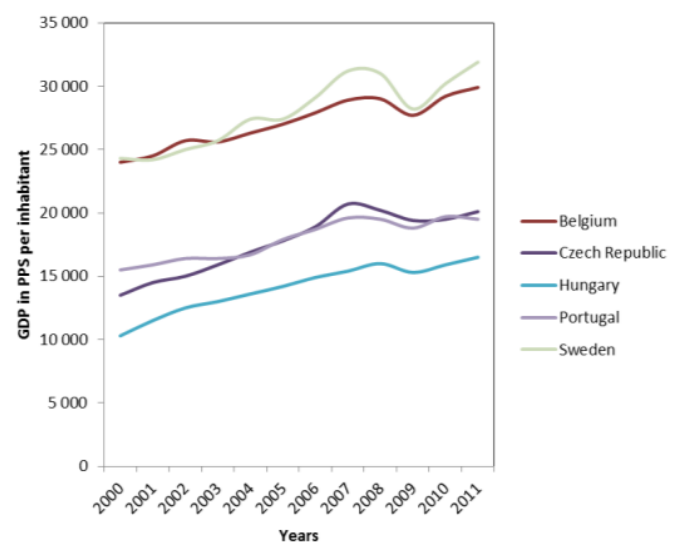

Fig. 1. Development of the gross domestic product in selected countries (In PPS per inhabitant).

Fig. 2 shows the development of exports in the selected countries in the years 2000-2011. In this case it is a monthly analysis for detailed view. It is expressed in million of euro.

In our analysis, we have reached the largest exporter is Belgium and Sweden. In Belgium there is export which is developing from 3530.6 to 8535.6 million of euro per month. In Sweden there is export which is developing from 2814.6 to 5067.7 million of euro per month. The contrast, Portugal is country which exports at least in comparison with other countries. There is development of exports from 360 to 1060.2 million of euro per month.

The average growth rate of GDP is the highest in the Czech Republic $(1.296 \%)$. It is followed by Hungary $(1.153 \%)$, Portugal $(0.758 \%)$, Belgium $(0.619 \%)$ and the last is Sweden with $0.412 \%$ average growth. This analysis also shows that the average growth rates are lowest in countries with a high level indicator. These values are in Table I.

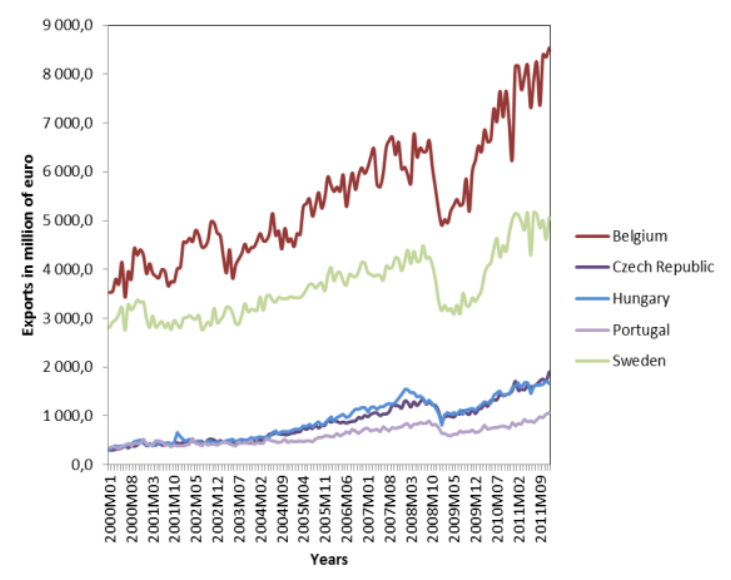

Fig. 2. Exports in selected countries (In million of euro, seasonally and working day adjusted)

The international trade isn't only characterized by export, there is also import. If we calculate export minus import we find the balance of trade. A Trade Balance, or Balance of Trade, is the difference between the monetary value of exports and imports of a specific country's economic output 
over a certain period of time. It is one of many economic fundamentals that affect the relative value of a country's currency. A positive or favorable balance of trade is known as a trade surplus when exports exceed imports. Conversely, a negative or unfavorable balance is referred to as a trade deficit or trade gap.

For detailed view Fig. 3 shows the development of balance of trade in selected countries. It is in million of euro per month, seasonally and working day adjusted.

This analysis shows that only one country has a positive balance of trade, it is Sweden. Only in this country there is export higher than import. In January 2000 there was a balance of trade 855.5 million of euro and in December 2011 there was balance of trade 1349.9 million of euro. In recent years the situation of international trade is the worst in Belgium. It is quite obvious in this figure.

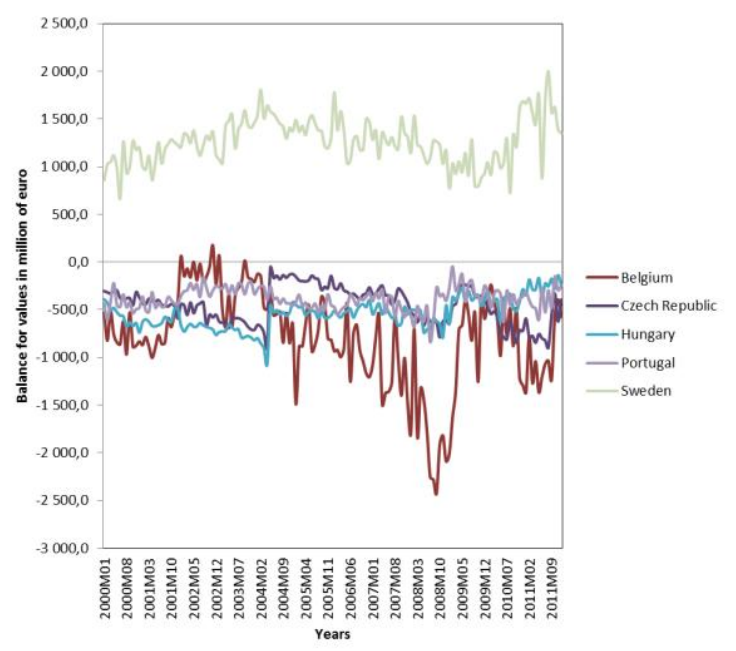

Fig. 3. Balance of trade in selected countries (In million of euro, seasonally and working day adjusted).

Our final summary of the development of these indicators (indicators for economic potential) in last chapter includes only average growth of rate of GDP and of export.

\section{A. Development Potential}

The development potential can be primarily characterized by conditions for the development of science and research and by conditions for foreign investors. We evaluate the science and research on the size of the expenditure for science and research. The level of research and development (R\&D) in the region is also affected the number of employees in science and research. Both of these indicators are further processed in graphical form (Fig. 4 and Fig. 5).

Fig. 4 shows the development of total $R \& D$ in selected countries in the years 2000-2011. It is expressed in euro per inhabitant.

At the highest level in R\&D expenditure is Sweden and it is followed by Belgium. Again these are two countries in leading positions as in the previous indicators. In Sweden there is development of $\mathrm{R} \& \mathrm{D}$ expenditure from 1112.30 to 1380 euro per inhabitant. The other country is Belgium where is the development of R\&D expenditure from 484.80 to 690 euro per inhabitant.

In this analysis there is a significant difference between the country with the highest R\&D expenditure and the country with the lowest R\&D expenditure. The lowest values are in Hungary. There is the development of this indicator from 39.6 to 120.6 euro per inhabitant.

If we look at average growth rate of this indicator we can see the highest value is in the Czech Republic (12.824\%) and in Hungary $(10.654 \%)$. It is followed by Portugal $(9.243 \%)$, Belgium (3.269 \%) and the last is Sweden (2.040\%). It shows Table I in the last chapter. This analysis shows the Czech Republic more and more invests to science and research.

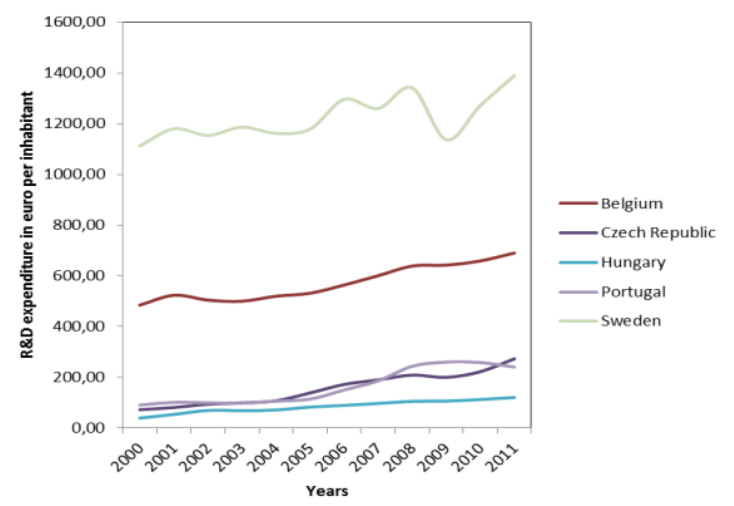

Fig. 4. Total R\&D expenditure in selected countries (In euro per inhabitant)

In our analysis we look at the number of employee in science and research for detailed view. The following figure, Fig. 5, shows the development of number R\&D personnel and researcher. It is in percentage of active population. Again on the top positions are Sweden and Belgium. But the figure shows one interesting fact and it is situation in Portugal. The number of personnel in R\&D is increased. In 2000 Portugal was the last and in 2011 Portugal is second. There is the development from $0.72 \%$ of active population to $2.05 \%$ of active population.

It means the average growth rate is the highest in Portugal with value $9.979 \%$. It is followed by Czech Republic $(3.815 \%)$, Belgium (1.468\%), Hungary $(1.375 \%)$ and Sweden $(0.308 \%)$.

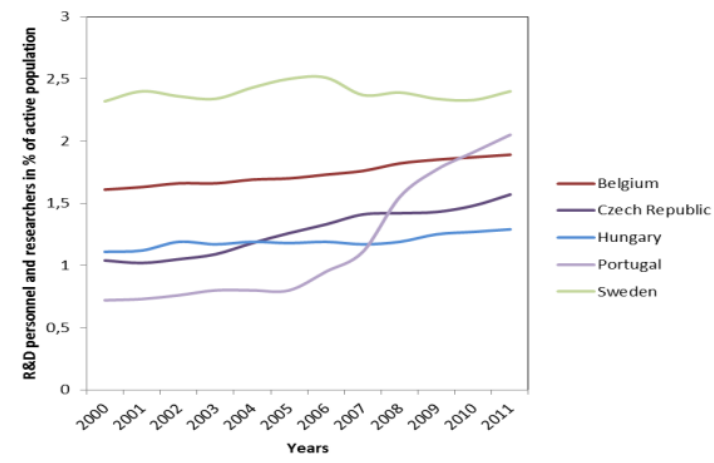

Fig. 5. Total R\&D personnel and researchers in selected countries (In percentage of active population).

In our final summary in last chapter there are both indicators, which are presented in the chapter, entitled Development potential.

\section{B. Human Potential}

The human potential is a very important factor in the economic sphere. The most important factor in the economy 
is people. In particular, the level of human capital is crucial for economic development. In this section in our analysis we deal with the educational level of the population of selected countries. Specifically, the college educated.

The last figure, Fig. 6, shows graduated in tertiary education. It is ISCED 5 and ISCED 6. ISCED is acronym for International standard classification of education. ISCED $5=$ Tertiary education (first stage) - entry to these programmes normally requires the successful completion of ISCED level 3 or 4 . This includes tertiary programmes with academic orientation (type A) which are largely theoretical and tertiary programmes with an occupational orientation (type B). The latter are typically shorter than type A programmes and aimed at preparing students for the labour market. ISCED $6=$ Tertiary education (second stage) - reserved for tertiary studies that lead to an advanced research qualification (Ph.D. or doctorate).

Belgium is in the highest position of graduates of tertiary education. But Sweden, the country which is in other indicators in the highest position too, is in the lowest position. The most significant development is in the Czech Republic, where is large increase. The contrary, in Hungary there is decrease from year 2005 .

This fact also shows analysis of average growth rate. It is the highest in the Czech Republic $(9.781 \%)$ followed by Portugal (5.463\%), Sweden (4.572\%), Belgium (4.021\%). And the last is Hungary with value $1.142 \%$.

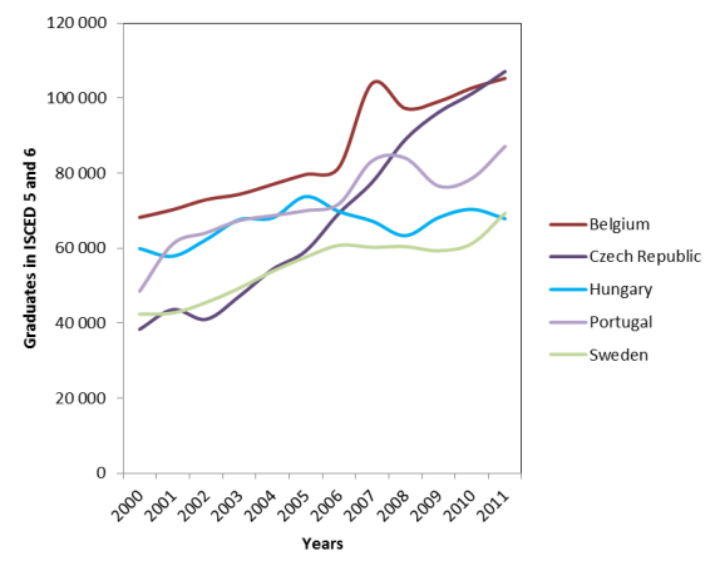

Fig. 6. Graduates in tertiary education (ISCED 5 and 6).

\section{The Position of the SELECTEd COUNTRIES}

In previous chapters there is an analysis of the development of indicators of regional disparities in economic sphere. The development is different in individual countries. For more detailed analysis of the development there are always calculated growth rates of development of indicators and the average growth rates of development of indicators during the monitored period. The average growth rates of indicators are summarized in following table. It is Table I, and these values are in $\%$.

If we look at the previous figures and analysis, we find that countries with the most common highest values are Belgium and Sweden. However, if we look at the average growth rates, we find that values of these countries are not the highest.

The highest value of average growth rate are reached in the
Czech Republic, it is in Export, R\&D expenditure and Graduates. This means the indicators of regional disparities in economic sphere in the Czech Republic reaches higher values than it is in other countries. It could be assumed Czech Republic is doing well and if all of this will grow as fast as at present it can overtake the countries which are on the top positions.

TABLE I: THE AVERAGE GROWTH RATE OF INDICATORS (IN \%)

\begin{tabular}{l||ccccc}
\hline \multirow{2}{*}{ Countries } & \multicolumn{5}{|c}{ The Average Growth Rate } \\
\cline { 2 - 6 } & GDP & Export & $\begin{array}{c}\text { R\&D } \\
\text { expenditure }\end{array}$ & $\begin{array}{c}\text { R\&D } \\
\text { personnel }\end{array}$ & Graduates \\
\hline \hline Belgium & 20.180 & 0.619 & 3.260 & 1.468 & 4.021 \\
\hline Czech R. & 3.684 & 1.296 & 12.824 & 3.815 & 9.781 \\
\hline Hungary & 4.376 & 1.153 & 10.654 & 1.375 & 1.142 \\
\hline Portugal & 2.108 & 0.758 & 9.243 & 9.979 & 5.463 \\
\hline Sweden & 2.504 & 0.412 & 2.040 & 0.308 & 4.572 \\
\hline \hline
\end{tabular}

The following table shows the sequence of indicators. It is separately for each monitored indicator. In fact it is a score of indicators. The rating is: the best value $=1$. the worst value $=5$. It is own data-processing. It shows Table II.

The Gross domestic product increases the most rapidly in Belgium. The export of products abroad increases the most rapidly in the Czech Republic. As well as the expenditure on science and research and the number of graduates increases the most rapidly there. And the number of workers in science and research increases the most rapidly in Portugal.

If we add up the score and there are the same conditions (the best value=the lowest value; the worst value=the highest value). We find the best situation is in the Czech Republic. There are indicators of regional disparities in economic sphere are increasing the most rapidly in the comparison with other monitored countries. The contrary, the lowest increase of indicators is in Sweden.

TABLE II: THE SEQUENCE OF THE AVERAGE GROWTH RATE OF INDICATORS

\begin{tabular}{l||ccccc||c}
\multicolumn{1}{c||}{} & \multicolumn{1}{|c|}{ The Sequence of the Average Growth Rate } & \multirow{2}{*}{ Summary } \\
\cline { 2 - 5 } Countries & GDP & Export & $\begin{array}{c}\text { R\&D } \\
\text { expen } \\
\text { diture }\end{array}$ & $\begin{array}{c}\text { R\&D } \\
\text { perso } \\
\text { nnel }\end{array}$ & $\begin{array}{c}\text { Gradua } \\
\text { tes }\end{array}$ & \\
\hline \hline Belgium & 1 & 4 & 4 & 3 & 4 & 16 \\
\hline Czech R. & 3 & 1 & 1 & 2 & 1 & 8 \\
\hline Hungary & 2 & 2 & 2 & 4 & 5 & 15 \\
\hline Portugal & 5 & 3 & 3 & 1 & 2 & 14 \\
\hline Sweden & 4 & 5 & 5 & 5 & 3 & 22 \\
\hline \hline
\end{tabular}

These findings are interesting and they should be a subject to further and detailed examination.

\section{CONCLUSION}

This article was focused on regional disparities in the economic sphere. There was analysis of selected countries of European Union. The aim of this article was to analyse of the development of regional economic disparities.

The main result of the analysis is that the selected indicators in individual countries are developing at different speeds. The most rapidly growth is visible in the Czech Republic. It means there is great potential for future cant other countries in these indicators. 
The analysis of economic regional disparities is a very interesting and important area and it is a large area. More research of the economic indicators of selected countries will be subject of further examination.

\section{REFERENCES}

[1] M. Hučka. A. Kutscherauer. P. Tománek. J. Sucháček, and M. Tvrdoň. (June 2013). Working Papers Regionalní Disparity. Metodologická východiska zkoumání regionálních disparit. [Online]. Available: http://disparity.vsb.cz/dokumenty2/wp_2.pdf.

[2] Ministry of Regional Development. (June 2013). Definition of Regional Disparities. [Online]. Available: http://www.regionalnirozvoj.cz/index.php/diskuze.437/items/definicepojmu-disparita.html.

[3] A. Kutscherauer, H. Fachinelli, J. Sucháček, K. Skokan, M. Hučka, P. Tuleja, and P. Tománek, Regionální disparity Disparity v regionálním rozvoji zemé. jejich pojetí. identifikace a hodnocení, $1^{\text {st }}$ ed. Ostrava: VŠB-TU. 2010. pp. 46-48.

[4] OECD. (June 2013). Regional Development. [Online]. Available: http://www.oecd.org/gov/regional-policy/regionaldevelopment.htm.

[5] R. J. Stimson, R. R. Stough, and B. H. Roberts. Regional Economic Development: Analysis and Planning Strategy, Revised edition, 2006. Berlin: Springer.

[6] P. Nijkamp, R. L. Moomaw, and J. T. Siedshclag, Entrepreneurship. Investment and Spatial Dynamics: Lessons and Implications for the Enlarged EU, Cheltenham, UK: E. Elgar Pub, 2006, pp. 238.

[7] I. Majerova, "International development cooperation of the Czech Republic in the context of European development," Prague Economic Papers, vol. 21, pp. 166-185, June 2012.

[8] R. Hušek, Aplikovaná Ekonometrie. $1^{\text {st }}$ ed, Praha: VŠE, 2001, pp. 270.

[9] M. Tvrdoň and T. Verner, "Examining the relationship between economic performance and unemployment: The Case of Visegrad Countries," in Proc. 29th International Conference on Mathematical Methods in Economics 2011, Jánska Dolina: University of Economics, 2011, pp. 733-738.

[10] Eurostat. (June 2013). Gross domestic product and other indicators. [Online].

Available: http://epp.eurostat.ec.europa.eu/NavTree_prod/everybody/BulkDownl oadListing?file=table_of_contents_en.pdf.
[11] K. Fojtíková and P. Tuleja, "Demographic progression of the Moravian-Silesian region," in Proc. 10th International Scientific Conference Economic Policy in the European Union Member Countries, Karviná: Silesian University, 2013, pp. 66-76.

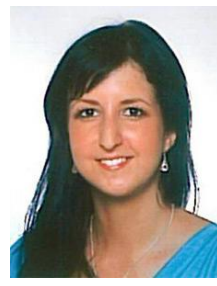

K. Gajdová was born in Ostrava in the Czech Republic on the $21^{\text {st }}$ of June 1986 . She studied business academy in Ostrava and then she studied at the Silesian University in Opava. School of Business Administration in Karvina. Now she studies for Ph.D. whereas she is employed as academic staff at the Silesian University. She also works for the Regional Development Agency. it is an institution dedicated to the development of Moravian-Silesian Region. She deals with the regional disparities and national economies. She has published many articles during her studies and work. for example: "Unemployment in the European Union context with selected indicators in 2010". "Changes in selected characteristics of the EU labour market in times of economic crisis" these papers were presented at a conference in Barcelona. Spain and these papers are in database Web of Science.

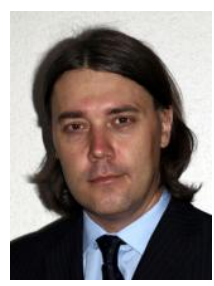

P. Tuleja was born in Ostrava in the Czech Republic on the $31^{\text {st }}$ of March 1971. He studied at the VŠB-Technical University of Ostrava. In 2008 he graduated successfully habilitation and he is associate professor and now he prepares for getting the title Prof Immediately after the study began working at the Silesian University in Opava. School of Business Administration in Karvina. Department of economics. Since 2010 he is head of department of economics. And since January 2013 he is the dean of the School of Business Administration in Karvina.

$\mathrm{He}$ is respected expert in the field of economic. policy and governance. Moreover he works in other public institutions. For example he is member of Committee of the Social Council of Moravian-Silesian Region. a member of the Expert Group for Strategy of Development of Moravian-Silesian Region and so on.

Whereas he works at the Silesian University he authored more than 180 publications in the field of economics, economy policy. etc. 